\title{
The Relation of the Majority and Minority of Religious People in
} Aceh Singkil

\author{
Arifin Zain ${ }^{1}$, Syahrin Harahap ${ }^{2}$, Hasan Bakti Nasution ${ }^{2}$ \\ ${ }^{1}$ Ph.D Student in State Islamic University of North Sumatera (UINSU), Medan, Indonesia \\ ${ }^{2}$ Lecturer in State Islamic University of North Sumatera (UINSU), Medan, Indonesia \\ zain.ifinzain@gmail.com
}

\begin{abstract}
Aceh Singkil is one of the districts in Aceh province that has a history of interreligious conflict. There have been several conflicts here, including in 1979 and in 2015. The conflict not only caused by disharmony but also caused by casualties and moral and material losses. The main problem in this paper is how relations are established between the majority and minority religious communities in Aceh Singkil. This research is a field research with qualitative analysis and data collection techniques used is in-depth non-structured interviews. The results of the study show that socially, the majority and minority religious groups coexist both in the areas of religion, social and culture and life is helping each other. Presumably conflicts arise due to several factors, including the weak enforcement of rules and the establishment of houses that are not in accordance with existing standards.
\end{abstract}

Keywords : Relation; Majority-Minority; Religious People

\section{Introduction}

Aceh is the only province in Indonesia that is given special rights in the fields of religion, education and customs. However, because it is under the Unitary State of the Republic of Indonesia, known as the Nation where Indonesia is a country consisting of various tribes, races, religions, and beliefs that recognize diversity, all of these groups have the same rights and are recognized by legislation without the slightest difference. Anyone who lives in Aceh, whatever his religion, tribe, and beliefs, must get equal treatment and equality before the law.

Social reality shows that in Aceh there are not only Muslims but also non-Muslims who are in a minority number. The Acehnese who are different from this religion, in their social life must come in contact with one another, both in the social, economic, political and cultural fields. Ideally, as a province that implements Islamic law, people who live in Aceh should have whatever their religion, ethnicity, or ethnicity must all live side by side and respect each other. In fact, so far there are still friction between religious groups. This friction is caused by several factors, both internal and external.

Historically, the people of Aceh were people who were used to religious nuances. This can be seen from the spirit of religious fanaticism and the spirit of carrying out religious teachings in everyday life. The teachings of Islam are influential in various dimensions of people's lives, such as in the fields of politics, social, culture and customs. That the implementation of Islamic teachings in Aceh has been carried out for generations so that it becomes an inseparable part of people's lives, so that in any case when the Acehnese do, the attitudes and behavior of their people are always identified with Islam.

Thus the influence of Islam in the lives of Acehnese people is so strong that Islamic teachings in the fields of worship, marriage and inheritance have been implemented for a long time, from the time of the sultanate to the present. Acehnese people are famous for being fanatical, and obedient to Islamic teachings. Various stereotypes circulated in the community, 
about the obedience and understanding of Islamic teachings of the Acehnese people, as well as the relationship and close relationship between tradition and shari'ah in the Aceh region. ${ }^{1}$

Socio-cultural reality shows that the Indonesian people are a religious nation, and believe in the Almighty God. The life of the Indonesian nation cannot be separated from the presence and development of major religions, such as Hinduism, Buddhism, Islam, Protestantism and Catholicism. Therefore, the growth and development of Indonesian socio-culture is strongly influenced and colored by religious values, because of that, then religious life cannot be separated from the life of the Indonesian people. ${ }^{2}$

So far the pattern of the majority-minority relationship has continued to live and even strengthened. Various issues of interreligious relations such as the issue of the establishment of houses of worship, religious broadcasting, religious rituals, interfaith marriage, and religious holidays and so on often involve the majority-minority mindset which results in violations of minority religious freedom, increasing attitudes intolerance and the birth of various discriminatory regulations.

In the course of history, Aceh, known as its Islamic community, finally had to be confronted with the presence of their compatriots who came from outside Aceh, especially North Sumatra, which was partly non-Muslim. On the other hand because trade and economic relations must accept the arrival of other nations who later became Acehnese, namely ethnic Chinese and Indians. This arrival finally led to the condition of the majority of Muslims and non-Muslim minorities in Aceh. As a result of this relationship history records that there have been several religious conflicts especially between Muslims and non-Muslims. Among the examples of cases of inter-religious conflict that occurred in Aceh Singkil in 1979 in the Simpang Kanan sub-district and in 2015 which claimed lives. This condition shows that the relationship between the majority of Muslims and non-Muslim minorities in Aceh if it is not managed properly and wisely will turn out to be a time bomb and has the potential to explode if less attention is paid to.

On the other hand, in one part of the Aceh Singkil area, it was found a village exactly Ujung Sialit village, Pulau Banyak Barat sub-district, which is located on the island of Tuangku, where the population is approximately 1,400 Protestant Christians. They were originally migrants from Nias district, North Sumatra. So far, there have not been any conflicts between indigenous people and the migrant population. Some of them even have embraced Islam and married local residents. Socially they are involved in community activities and participate in various activity programs.

Seeing the conditions above, this research is important to do to examine in detail the relationships that are woven by Muslim and non-Muslim communities. That the impact of different ideological and cultural relations on the one hand may be integrated but on the other hand there will be disintegration or conflict between religious groups.

\footnotetext{
${ }^{1}$ Al Yasa Abubakar, Syari`at Islam di Provinsi Nanggroe Aceh Darussalam : Paradigma, Kebijakan dan Kegiatan, (Banda Aceh : Dinas Syari`at Islam Provinsi Nanggroe Aceh Darussalam, 2005), P. 26-27.

${ }^{2}$ Syahrin Harahap, Teologi Kerukunan, (Jakarta: Prenada Media Group, 2011), P. 47.
} 


\section{Review of Literature}

\subsection{Categorization of Minority Groups}

In sociology studies, there are several types of minority groups, namely: Racial Groups, Ethnic Groups, Religious Groups; and Gender Group. First, the Race Group, about racial groups found two different perceptions, namely whether the determination of race factors are the reality of skin color alone or other factors that can be seen clearly. ${ }^{3}$ This grouping of races can also be seen from the skin color element. This method of grouping only concerns skin color differences, white (bluish, reddish, brown spots, etc.) black (bluish), yellow (brown) brown (blackish or reddish), red (blotchy or whitish). Second, based on ethnicity, ethnic minorities can be distinguished from the dominant group based on cultural differences, the more popular use of language (dialect, slang, etc.), attitudes toward marriage, the concept of family, eating habits, and so on. The three religious groups, for example, that Middle Eastern society is a vertically segmented society or divided into vertical segments that are social, economic, and political in the horizontal segments of ethnicity / religion. ${ }^{4}$

\subsection{History of Minorities in Islam}

At the beginning of its presence, Muslims were once a minority group whose rights were neglected. Even when in Makkah the position of the prophet Muhammad and his followers was in the condition of an oppressed minority. However, related to the minority situation in Medina, the prophet Muhammad and his followers from the host of Medina also reached an official political agreement. The Prophet Muhammad and his followers formed a political group along with the Medina clan, called the ummah, even though this term was intended for the Muslim community. Makkah Muslims and citizens of Medina must act as a unit to defend Islam and Medina from outside parties. None of the clans is allowed to form separate peace.

In the time of friendship, although it was not entirely the same as in modern times, the principles of religious freedom in classical Islam are the same as those that exist today. Even if it is not an exaggeration to say that religious freedom in modern times is a further development that is consistent with what is in classical Islam. Examples of religious freedom in classical Islamic societies are reflected in an agreement made by Umar Ibn al-Khaththab with residents of Jerusalem or Bait al-Maqdis, al-Quds after the holy city was liberated.

Collaborating with other religious people in worldly affairs, for family principles as exemplified by the Prophet above, is not a synergy of faith, but tolerance between religious groups. Every religion in principle is impossible to combine in a synchronic way, but with a bond of brotherhood, people from all religions can unite and make peace with all the differences as a big family. So, when the Prophet Muhammad was moved to remember the late Abu Talib, his idol uncle and contributed to the defense of Islam during his lifetime, it did not mean that the Prophet dissolved his Islamic religion with the religion of Abu Talib, his uncle. This is nothing but the empathy of humanity.

\footnotetext{
${ }^{3}$ Alo Liliweri, Prasangka \& Konflik : Komunikasi Lintas Budaya Masyarakat Multikultur, (Yogyakarta: LKis, 2005), P. 114.

${ }^{4}$ Alo Liliweri, Prasangka \& Konflik, P. 119.
} 


\subsection{Definition and Function of Conflict}

In language, conflict means a fight, war or struggle, which is a physical confrontation between several parties. The meaning of the word then developed with the inclusion of sharp disagreements or opposition to various interests, ideas and others. In other words, the term now also touches the psychological aspects behind the physical confrontation that occurs, in addition to the physical confrontation itself. In a singular manner, the term conflict became so widespread that it was at risk of losing its status as a single concept. ${ }^{5}$

Conflict is a clash. Another word for conflict is clash, which also means the same, collision. Conflict can occur between two hostile parties, or between two opposing elements or ideas. The end of conflict is war. Not infrequently, to refine language, the term war is often termed conflict. There is armed conflict, there is political conflict, and even now what is very well known is conflict / clash of civilizations. When a collision occurs, of course something changes, especially the nature, attitude and form. When a collision occurs, neither of them must win, but maybe both of them lose, in the sense that changes occur, both aspects and substance. The shape will metamorphose to a condition that is different from before. ${ }^{6}$

Function of conflict, First, conflict is a fertile nursery for social change. People who consider the situation they are facing unfair or assume that the current policy of fools usually experiences opposition to the prevailing rules, for example, almost every new law in the US Congress is implemented after debate and pressure from opposition groups. Second, the second positive function of social conflict is that the conflict facilitates the achievement of reconciliation of various interests. Most conflicts did not end with victory on one side and defeat on the other side. Conversely, some of them are in the form of integrative agreements which benefit both parties and provide greater collective benefits to their members often occur.

Third, on the basis of the first two functions, conflict can strengthen group unity. Without the capacity for social change or reconciliation of different individual interests, group solidarity seems to be deteriorating - by bringing together group effectiveness and enjoyment of group experiences. $^{7}$

There are several factors that need to be observed in connection with the occurrence of social conflicts that piggyback on ethnic and religious factors behind them. First, we must realize that ethnic movements are a movement that emerged as a response to capitalism and human culture based on modern technology, communication, and information, which also gave birth to a new model of homogeneity throughout the world. Secondly, ethnic conflicts occur due to the fragility of state institutions that overshadow the diversity of society. The state is no longer able to provide and fulfill the basic needs of the community, while satisfying alternative structures are not yet available. Previously, a power system that in a certain period of time was able to control power over separate groups. The state succeeded in creating a certain order in which differences of opinion and small parts were highlighted and held back by orbits controlled by central gravitational forces. Third, the emergence of ethnic movements in a country is caused by strong political pressure through the issue of democratization, human

\footnotetext{
${ }^{5}$ Dean G. Fruit dan Jefrey Z. Rubin, Teori Konflik Sosial, terj. HALelly R. Soetcipto, (Yogyakarta: Pustaka Pelajar, 2011), P. 9.

${ }^{6}$ Yusny Sabi, Pengantar : Batang Konflik Dimana Tumbuhalnya, dalam Zulkarnaini Abdullahal, dkk, Akar Konflik Manusia, (Banda Acehal: Ar-Raniry Press, 2003), P. ix-x.

${ }^{7}$ Dean G. Fruit dan Jefrey Z. Rubin, Teori Konflik, P. 15.
} 
rights, and the environment. This issue succeeded in inspiring various ethnic groups and religions in a country, especially in the third world, to express opposition to the state.

In recent years, the theory of integration about society clearly dominated the thinking of sociology. This habit of seeing one side has caused various unfavorable consequences. However at least there is also one pleasant effect, where the one-sided view of this theory also raises critical denials so that it allows us to unite to put this theory in its proper place.

\section{Research Methods}

This research is a qualitative field research. Qualitative research is used in many disciplines separately, the approach does not have a particular set of methods that are entirely the research. The approach used is the Interdisciplinary approach, because the research problem that will be studied is the relations between religious groups in Aceh Singkil, such as the religious, social and cultural fields. With an interdisciplinary approach it is hoped that the actual patterns of relations in society will be found and also in what areas they will be integrated and in what fields they will be different.

Even this research is classified as a case study. Case studies are a type of approach in research where the review of a case is carried out intensively, deeply, in detail, and comprehensively. Case studies can be carried out on individuals, as is usually done by experts in analytical psychology; can also be done with groups, as practiced by some Anthropologists, Sociologists, and Social Psychologists. ${ }^{8}$ Qualitative research with a case study approach focuses on knowing diversity and specificity (particularities) from the object of study that was the target of his research. However, the final results to be obtained are an explanation of the uniqueness of the case he was carrying out. ${ }^{9}$

Given the size of the research area, the researchers restricted themselves to two subdistricts, namely Simpang Kanan and Gunung Meriah sub-districts. The selection of these two sub-districts with consideration, first, the Simpang Kanan and Gunung Meriah Sub districts are sub-districts which experience inter-religious conflict. Secondly, Simpang Kanan and Gunung Meriah sub-districts are relatively sub-districts with a large number of non-Muslim communities and spread across several villages.

To simplify work, the source of research is determined by purposive sampling technique. Purposive sampling is used considering that in this study the data to be sought is the depth of information about relations between religious people in the social, political and economic fields. Based on the above, the sources of data in this study are as follows: Aceh Singkil Regency Government, Ulama, and Community Leaders. Determination of research data sources cannot be stated with certainty, because in qualitative research the number of research subjects is very conditional and highly dependent on the quality of the chosen subject.

Interviews are conducted in depth to obtain detailed data about the problems being studied. Interviews used are non-structured interviews with the consideration that researchers have mastered the problems to be studied and provide opportunities for researchers to ask questions that may not have been planned in advance. ${ }^{10}$

\footnotetext{
${ }^{8}$ Sanapiah Faisal, Format-format Penelitian Sosial, (Jakarta: RajaGrafindo Persada, 2007), P. 22.

${ }^{9}$ Agus Salim, Teori dan Paradigma Penelitian Sosial, P. 97.

${ }^{10}$ Djam`an Satori dan Aan Komariah, Metodologi Penelitian, P. 136.
} 
This technique is used to obtain complete and comprehensive information about the relationship between the majority of Muslims and non-Muslim minorities in Aceh. Among the documents studied are relevant books, journals.

As a qualitative research, the steps in the qualitative data analysis process are first, Data Reduction, namely choosing the main things, focusing on the important things, looking for themes and patterns. Second, Data Display (Presentation of Data), with display data, then the data presentation will be organized and arranged in a relationship pattern so that it is more easily understood. Third, Conclusion drawing, draw conclusions. Conclusions in qualitative research are tentative conclusions, if no new evidence is found, the conclusion is a credible conclusion.

\section{Discussion}

In terms of diversity, the majority of Muslims and minority non-Muslims live in mutual respect, for example every month of fasting, a letter is sent to every non-Muslim house so that their shop is closed. Although the shop is open, curtains must be made. Fasting month, all stalls are closed, indeed there are no restaurants here, only ordinary stalls or stalls. The aim is to respect and respect our Muslim brothers who fast. In the fasting month there were no nonMuslims who ate on the streets. At the time of Eid, or on the feast, in the morning after completing the prayer of Al Fithri, we go around and deliver food or cakes. Likewise those who invite us to come to eat together Muslims. From our side, non-Muslims usually only provide raw food such as pulut rice or sugar because it is not possible to cook. This is how we are in this village. ${ }^{11}$

Another example, a few moments ago there was a dhu afa house assistance program for the poor from the Lake Paris sub-district. As the village head, we convey that there are our brothers who are Muslims here who are entitled to a house of assistance. Once informed, they immediately come and go down to the location to see what we have to say. I also need to say that we have three brothers, and my younger brother who now lives on Lake Paris, has become a Muslim. It seems impossible, only because of this religion that we clashed. ${ }^{12}$

Related to the demolition of one church, one source said that speaking of religion is not only local, but must be international, especially with the current state of the world. For example, after the demolition of the church, then Christians put up tents, this is not great for Muslims, but rather makes Islam worse in Aceh. Every time there is an incident, non-Muslims invite international media and then shoot to show how cruel the Muslims in Aceh are, that is what is raised. if this is the case it is better not to dismantle the churches, because the impact is greater on Islam in the eyes of the international community. We are not sure if the one who burned the church was a Muslim, they might burn themselves, and this has been proven in the dating area. $^{13}$

Another village where Muslims are a minority is the village of Lae Geuci, which has 121 families, while non-Muslims comprise only 5 families, the rest are non-Muslims. Likewise with Tutuhan village where Muslims only consist of 2 families, so they become a minority.

\footnotetext{
${ }^{11}$ The results of interviews with TP, Christian community leaders.

12 The results of interviews with TP, Christian community leaders.

${ }^{13}$ Interviews with ZAT, Muslim community leaders.
} 
Even so, the social life here is going well, even one of our family members who is married to a Muslim from Fajar City, South Aceh. As far as we go, here there is no intimidation. ${ }^{14}$

The reality of togetherness that happened was indeed not pretending, from the past so until now in general there had been no conflict in the community until now. This happens because it is possible because by custom, the clan is the same in Islam or in Christianity. There is Christian Berutu, Berutu Islam, there is the Christian Bead and there is a Manik Islam. With the existence of clan similarities, they cannot be playful and truly bound. So, from this point of view tradition is still built, and overall there is no problem if there are activities that remain together. ${ }^{15}$

There is no problem with social interaction between religious communities until now, because they greet each other, respect each other, rebuke each other. This is what is always conveyed in every meeting that there is no conflict between people, Muslims and Christians still get along. Conflict arose due to regulatory issues regarding the establishment of places of worship. That Christians set up houses of worship outside the initial agreement agreed upon by Muslims with Christians, but the agreement continues to be ignored. Muslims neglected and non-Muslims ignored the agreement so that it last developed into 24 churches even though the 5 places of worship agreed with the provisions of 1 Church and 4 Undung-Undung. ${ }^{16}$

While related to Muslim houses of worship in the majority of non-Muslim regions, it was explained that indeed in Lae Geuci village there was no mushalla. Muslims have asked, but we say, just use the village hall first. Ideally made first here is TPA. With the existence of TPA, later the development of mushalla can be proposed, because this is getting faster attention from the government. But it seems that our brothers and sisters here don't seem to think that way, however they are Muslim converts not native to Muslims. ${ }^{17}$

In social life, the relationship is good, for example when we hold activities such as parties, we invite each other, Muslims invite Christians and we invite Muslims. Food is also separated between Muslims and non-Muslims, especially here non-Muslims are more than Muslims, Muslims are around 30\% and non-Muslims are 70\%. Social life here is very strong but problems arise related to the matter of permitting houses of worship. ${ }^{18}$ Even every year in this village there are mutual assistance activities assisted by security forces such as Koramil. Like what happened two months ago, the first cooperation in the mosque was carried out after that in the church, all of us participated together. ${ }^{19}$

This social life can also be seen from events in the community, such as wedding parties. If there is an activity such as a wedding party, for Muslim food we submit it to Muslims. Usually if you hold a wedding party we don't invite outside Muslims that we invite only Muslims who are here. For Muslim guests there is a separate set and we ask our Muslim brothers to sit there. This can be seen from the attendance book (guest-researcher book), because the system here is every invitation that comes, note its name. So anyone who does a party here, whether Muslim or non-Muslim, is all like that. So based on this, it can be said that socially in life there is no friction. ${ }^{20}$

\footnotetext{
${ }^{14}$ The results of interviews with TP, Christian community leaders.

15 The results of the interview with the Chairperson of the Aceh Singkil FKUB.

16 The results of the interview with the Chairperson of the Aceh Singkil FKUB .

${ }^{17}$ The results of interviews with TP, Christian community leaders.

${ }^{18}$ Results of interviews with LM, a Christian religious leader.

${ }^{19}$ Interview with HM, a Christian.

${ }^{20}$ The results of interviews with TP, Christian community leaders.
} 
The same thing was revealed by other data sources that in social activities they collaborated with each other, regardless of their village. Only if food for Muslims is usually ordered at catering or we ask Muslims to cook special food for Muslims. These foods are served for Muslim guests. Likewise, during Eid if there were close Muslim friends, we visited each other in greetings. When Eid we usually given to them like rice, so also when we commemorate the New Year they also come. ${ }^{21}$

The statement above was confirmed by one of the speakers who said that in social activities they invited each other as well as vice versa. However we are a village, only if food for Muslims is usually ordered at catering or we ask Muslims to cook special food for Muslims. These foods are served for Muslim guests. It is also the case at the time of Eid if there are close friends of Muslims, we visit each other greetings when we usually give them love as rice, so also when we commemorate the New Year they also come. Likewise, when there are Muslims who die, we come to visit because they are socially our neighbors. These are friends of the same village, who we live with, help each other and help each other. Likewise, when there were people who died, Muslims also came to visit, but if there was tahlil, we usually didn't come. ${ }^{22}$

He added that there were social activities carried out jointly or in mutual cooperation, such as cleaning the road together. The Suka Makmur village community in farming knows the term mardang, which is to plant rice together. In this mardang rice planting activities are carried out in mutual cooperation regardless of Muslims or non-Muslims ${ }^{23}$. In my view, the socio-cultural life in Aceh Singkil runs normally because we value Muslims and they also respect us, for example in the culture of Muslims and Christians there is the term mitumba and tor-tor. ${ }^{24}$

Here, local wisdom is also found, because the community adheres to a group system, but this mutual cooperation system is somewhat disturbed since the village funds were available. If people are invited to work together, they are reluctant to come. Even though previously mutual assistance activities were always carried out. For example in rice planting there is a term whose name is mardang. Mardang is planting rice using wood together activities like this are often done. This collaboration is carried out by Muslims with non-Muslims. For example if today our fields are done, then the next day someone else fields. ${ }^{25}$

So it can be said that the participation carried out by Christians in the community such as participating in mutual cooperation activities. Together with the Muslim community, we clean the village and make trenches for the common good. The point is mutual tolerance, mutual respect for one another, and so together to discuss in planning village development. As a minority group we feel there is no pressure from the majority Muslim group because we live in mutual respect for no pressure we experience. When a conflict between citizens is resolved by means of deliberation and forgiveness, mutual respect is because if we do not respect Muslims it is likely that they will expel from Aceh Singkil. ${ }^{26}$

Human diversity is a predetermined sunnatullah since humans existed. The diversity of nations, races, tribes, customs, cultures and even religions is a form of God's power that is demonstrated through His creation. However, these differences cannot be used as arguments

\footnotetext{
${ }^{21}$ The results of interviews with Ms. Mi are Christians.

${ }^{22}$ Interview with Ms. Mi.

${ }^{23}$ Interview with Ibu Mi.

24 The interview with Ms. Sr., a Christian.

25 The results of interviews with TP, Christian community leaders.

26 The results of the interview with Mr. R are Christians.
} 
to claim that a nation becomes a ruler for other nations or tribes, but becomes an adhesive to understand one another. Al-Quran itself states that the problem of difference is a sunnatullah which must be seen as a potential possessed by humans, both because of differences in sexes such as men and women, tribes and nations.

Good cooperation if not cared for and taken seriously can result in conflicts between groups, both conflicts in the religious, political, economic and social fields. In the case of Aceh Singkil, the collaboration that has already been established has also finally led to the emergence of religious conflicts in the sense of conflict over permits to build houses of worship. This is because of two factors, namely internal and external. Internal factors are factors of conflict originating from the religious community itself, in this case the Christians who built the church outside the initial agreement and the indication of carrying out covert preaching to Muslims.

Al-Quran itself states that the problem of difference is a sunnatullah which must be seen as a potential possessed by humans, both because of differences in sex such as male and female, ethnicity and nation. The Word of God in the Qur'an the letter al-Hujurat: 13 which means:

"O mankind, verily we created you from a man and a woman and made you nations and tribes so that you would know one another. Surely the noblest of you in the sight of Allah is the one who has the most fear among you. Lo! Allah is Knower, Knower."

For Quraish Shihab, whatever the origin of the verses above, the essence of the verse confirms the unity of human origin by showing the similarity of humanity. So it is not natural for someone to feel proud and feel themselves taller than others, not only between one nation, tribe, or skin color with others, but between their sexes ... The word ta arafu in the above verse is taken from the word arafa which means to know. The word patron used in this verse contains reciprocal meaning, thus means getting to know each other. So the stronger the recognition between one parties to the other, the more opportunities will be given to each other. So this verse emphasizes the importance of getting to know each other. This introduction is needed to attract each other's lessons and experiences of others, in order to increase piety to Allah whose impact is reflected in the peace and well-being of worldly life and ukhrawi happiness.

The wisdom is to make people with tribes and nationalities so that people know other passages and do not attribute each other to other than their ancestors. Such creation is not to mutually boast the origins of fathers, ancestors and offspring. Although this was considered in adat and shari'a so that syarifah should not be mated with ordinary people. It's just that it is worthless if without faith and piety.

During the Messenger of Allah in Mecca, when Islam was only revealed, Muslims known as the Awwalun Assabiquunals became minorities, minorities in terms of numbers, and minorities in political influence, minorities in the religious and minority sectors in the economy but the majority in the field of spirit and faith. Conversely when in Medina, from the initial minority position then changed to the majority group, even the apostle made a policy known as Piagama Madinah to regulate the relationship of the majority of Muslims with the nonMuslim minority in Medina.

\section{Conclusion}

Relations between religious communities in Aceh Singkil district run well in accordance with the patterns of relations in sociological reviews such as cooperation in sharing dimensions of life such as social, political and economic fields. The reality of these relationships has a good impact on social life and harmony among religious people, however, inter-religious conflicts 
continue to occur due to violations of the permission to establish places of worship. Socially there are no obstacles in inter-religious relations in Aceh Singkil district, new obstacles occur related to the establishment of places of worship.

\section{References}

A. Mukti Ali, Ilmu Perbandingan Agama di Indonesia, Yogyakarta: IAIN Sunan Kalijaga Press, 1988.

Agus Salim, Teori dan Paradigma Penelitian Sosial, (Pemikiran Norman K. Denzin dan Egon Guba dan Penerapannya, Yogyakarta: Tiara Wacana Yogya, 2001.

Al Yasa` Abubakar, Syari`at Islam di Provinsi Nanggroe Aceh Darussalam : Paradigma, Kebijakan dan Kegiatan, Banda Aceh : Dinas Syari’at Islam Provinsi Nanggroe Aceh Darussalam, 2005.

Alo Liliweri, Prasangka \& Konflik : Komunikasi Lintas Budaya Masyarakat Multikultur, Yogyakarta: LKis, 2005.

Clifford Geertz, Kebudayaan dan Agama, terj. Fransisco Budiman, Jakarta: Kanisius, 2003.

Dean G. Fruit and Jefrey Z. Rubin, Teori Konflik Sosial, terj. HALelly R. Soetcipto, Yogyakarta: Pustaka Pelajar, 2011.

Elizabet K. Nottingham, Agama dan Masyarakat : Suatu Pengantar Sosiologi Agama, Jakarta: Raja Grafindo Persada, 1996.

Hamka Haq, Islam Rahmah Untuk Bangsa, Jakarta: RMBOOKS, 2009.

Hartini and G. Kartasapoetra, Kamus Sosiologi dan Kependudukan, Jakarta: Bumi Aksara, 1992.

Harun Nasution, Islam Ditinjau dari Berbagai Aspeknya, Jld. I, Jakarta: UI-Press, 2012.

Ira. M. Lapidus, Sejarah Sosial Umat Islam, Bagian I dan II, terj. Ghufron A. Mas`adi, (Jakarta: RajaGrafindo Persada, 2000), P. 39-40.

Muhammad Ali ash-Shabuni, Shafwatut Tafasir, terj. Yasin, Jakarta: Pustaka Al-Kautsar, 2001.

Nurchalolis Madjid, Islam Doktrin \& Peradaban, Jakarta: Paramadina, 2005.

Paul B. Horton and Chester L. Hunt, Sosiologi, terj. Aminuddin Ram dan Fita Sobari, Jakarta:Erlangga, 1984.

Peter Salim, The Contemporary English-Indonesian Dictionary, Jakarta: Modern Englishal Press, 1986.

Quraish Shihab, Tafsir Al-Mishbah, Vol. 13, Jakarta: Lentara Hati, 2007.

Ralf Dahalrendropf, Konflik dan Konflik dalam Masyarakat Industri, Sebuahal Analisa Kritik, terj. Ali Mandan, Jakarta: Rajawali, 1986.

Robert N Bellah, Beyond Belief : Essays on Religion in a Post-Traditional World, New York: Harper \& Row Publishers, 1976.

Sanapiah Faisal, Format-format Penelitian Sosial, Jakarta: RajaGrafindo Persada, 2007.

Soejono Soekanto and Mustafa Abdullah, Sosiologi Hukum dalam Masyarakat, Jakarta: Rajawali, 1982.

Syahrin Harahap, Teologi Kerukunan, Jakarta: Prenada Media Group, 2011.

Tim Penyusun Kamus Besar Bahasa Indonesia, Kamus Besar Bahasa Indonesia, Jakarta: Media Pustaka Phaloenix, 2012.

William A. Haviland, Antropologi, terj. R. G. Soekadijo, (Jakarta: Erlangga, 1985), -. 215.

Yusny Sabi, Pengantar : Batang Konflik Dimana Tumbuhalnya, dalam Zulkarnaini Abdullahal, at el, Akar Konflik Manusia, (Banda Acehal: Ar-Raniry Press, 2003), -. ix-X. 